\title{
Influence of School Certificate English Achievement and Faculty on Course of Study
}

\author{
Vincent U. Uguma ${ }^{1} \&$ Alexander E. Timothy ${ }^{1}$ \\ ${ }^{1}$ Department of Curriculum and Teaching, University of Calabar, Calabar, Nigeria \\ Correspondence: Vincent U. Uguma, Department of Curriculum and Teaching, University of Calabar, Calabar, \\ Nigeria. Tel: 234-70-6861-8947. E-mail: vincentuguma@gmail.com
}

Received: July 18, 2014

doi:10.5539/hes.v5n1p81
Accepted: December 16, $2014 \quad$ Online Published: January 21, 2015

URL: http://dx.doi.org/10.5539/hes.v5n1p81

\begin{abstract}
The study was to find out the influence of both students' achievement in the West African Examination Council's Senior School Certificate English Language examination and the faculty of study by the students in the university on their performances in Use of English and in specific courses of study. 964 undergraduate students of Cross River University of Technology, Calabar, Nigeria, were sampled for the study. The students' results in the Senior School Certificate English Language examination, scores obtained by them in the Use of English course at the university and their cumulative grade point averages in their specific courses of study at the university were the data collected and used for the study. Four hypotheses were postulated and tested at 0.05 level of significance, using mean, standard deviation and analysis of variance as statistical tools. It was found out that achievement in the Senior School Certificate English Language examination and Use of English course at the university contribute significantly to the variance in students' academic performance in specific courses of study; significant differences exist in the academic achievement of students in various faculties in the Senior School Certificate English Language examination; faculty of study does not significantly influence students' academic achievement in Use of English, and faculty of study does not significantly influence academic performances in specific courses of study. The study thus canvassed that admission of students into different faculties in the university should not be determined by their level of achievement in the Senior School Certificate English Language examination.
\end{abstract}

Keywords: achievement, course, faculty, influence

\section{Introduction}

The status and utilization of English in Nigeria as a lingua franca cannot be overemphasized as it serves as a socializing agent among speakers. In communicative language, it enables users to relate or socialize better among themselves. In the school setup, a pass at credit level in the Senior School Certificate examination is a prerequisite for admission into the university. It is a language of science, technology, aviation and broadcast (Baugh, 1982), and cuts across our social strata and multi-ethnic situation (Yusuf, 2000). It is a worldwide language (Ezema, 2000). Thus, if poor performance by candidates is recorded, it means that the nation's quest for human capital development will be in danger (Nimyel, 2010). Admission into any course of study in any faculty at the university is determined, to a far extent, by candidates' achievement in the Senior School Certificate English Language examination.

Use of English is a course that is offered in all Nigerian universities. Its aim is to imbue in undergraduates ability to carry out communication both orally and written so as to cope with the academic needs in various programmes of study. This is because all academic work is carried out through the medium of English Language in all faculties. The course also focuses on appropriate and correct English Language use by exposing students to the skill of developing effective plan of study in the courses of study by the students. More so, the course enables students to be efficient and proficient English Language users for their academic activities and for use in communication within and outside the university environment.

From the foregoing, it is clear that the Senior School Certificate English Language examination is intended to test compliance to set standards in the use and application of English Language both in school and out of school. The Use of English course at the university consolidates and strengthens the gains of the knowledge of English Language at the secondary school level so as to provide ample opportunity for learners to succeed in their 
specific courses of study at the university. Therefore, the study was to find out if their performances in the Senior School Certificate English Language examination and the faculty into which they have been admitted have any influence on their performances in the Use of English course, and in their specific courses of study at the university.

\subsection{Statement of the Problem}

It is the desire of every human being to be appreciated particularly when a task has been successfully accomplished. The student who goes to school will like that at the end of the academic carrier, efforts put in are rewarding in terms of excelling in the academic work. In a normal situation the knowledge of English Language gained by the students at the secondary school level should enable them cope with academic work in their courses of study at the university, particularly where the medium of instruction is the English Language.

However, there is a controversy among students and would- be students at the university level that the level of achievement in the Senior School Certificate English Language examination determines the level of success in the Use of English course at the university and in the students' specific courses of study, since teaching and learning take place through the medium of English Language. Again, it is contended that the various faculties at the university into which students are admitted influence the students' performances in the Use of English course and in the specific courses of study by the students. This contention is also premised on the assertion that academic activities in some faculties are more given to prolong talking in English Language than others where short statements are used to represent a lot that would have been spoken or written. Thus, those admitted into the former are more prone to talking and that leads to perfecting in language use than the latter. The problem of the study therefore was: does the level of achievement in the Senior School Certificate English Language examination determine, or influence students' performances in the Use of English course and, ultimately, in the students' specific courses of study? Again, does the faculty of academic study by a student determine or influence achievement in academics either positively or negatively?

\subsection{Hypotheses}

The researchers postulated the following hypotheses which guided the study:

1) Students' faculty of study, academic achievement in the Senior School Certificate English Language examination, and Use of English do not significantly contribute to the variance in their performances in specific courses of study.

2) There is no significant difference in the academic achievement of students in various faculties in the Senior School Certificate English Language examination.

3) There is no significant influence of faculty of study on students' academic performance in the Use of English course.

4) There is no significant influence of faculty of study on students' performance in specific courses of study.

\subsection{Assumptions}

During the study, the following assumptions were made.

1) The curriculum content and method of teaching the Use of English course in the various campuses of the university were uniform.

2) The grades/scores obtained by each of the students in the Senior School Certificate English Language examination were genuine reflections of their personal academic abilities.

3) Students' scores in the Use of English course and those in their specific courses of study were true reflections of their individual academic abilities.

\subsection{Literature Review}

Dagila (2010) researched on performance of students in the Senior School Certificate English Language examination as a predictor of performance in Use of English course at the university. The researcher used a sample size of six hundred and seventy five (675) students drawn from government owned secondary schools in Katsina State, Nigeria. The instruments for data collection were the students' scores in the Senior School Certificate English Language examination and their scores in the Use of English course. The researcher concluded that poor performance of students in English in the Senior School Certificate does not mean that performance will be poor in the Use of English course at the university. This is because there is the probability for the students to improve in the English Language mastery, thus, reversing the trend of the performance in the Senior School Certificate English Language examination. 
The study by Hussein (2009) was on the relationship among undergraduate students' achievement in the Senior School Certificate English Language examination, their level of performance in the Use of English course and in their individual courses of study. The result of the study showed a significant relationship among achievement in the Senior School Certificate English Language examination, performance in the Use of English course, and in their specific courses of study. Also, Lawani's (2011) study was on the correlation between the achievement of under graduate students in their Senior School Certificate English Language examination and their performances in the Use of English course at the university. With a sample size of 500 students, the result showed that achievement in the Senior School Certificate English Language examination correlated with that of Use of English course at the university.

Geishina (2008) studied students' achievement in the Senior School Certificate English Language examination to find out if the achievement correlates with that of Use of English at the tertiary institution. The study involved seven hundred (700) students from three universities in the Middle Belt Zone of Nigeria. The result of the study showed that there was correlation between achievement in the Senior School Certificate English Language examination and that in the Use of English course. This means that those who did well in the Senior School Certificate English Language examination also did well in the Use of English course in the university.

The study by Fagbemi (2008) was on the influence of faculty on the self-esteem of students and their performance in courses of study. The researcher sought to find out if admission of students into a particular faculty in the university dampens or boosts their ego and its influence on performance in academics. The respondents were nine hundred (900) students randomly drawn from five faculties from the University of Ibadan, Nigeria. Through a structured questionnaire the researcher found that there was no significant influence of the faculty a student was admitted into on performance in academics. The study revealed that students' performances were determined by the consciousness of their desire to learn, as any course could propel them to the highest academic stratum, if conscientiously studied.

Aneke (2009) studied correlates between students' performance in the Senior School Certificate English Language examination and their performances in faculties of study. The researcher used a sample size of four hundred and eighty (480) students for the study. The finding showed no positive relationship. Toffai (2007) researched on students' performance in Use of English and the effect on achievement in academics in different faculties. The researcher drew a sample size of five hundred and forty (540) students from Kwarra State, Nigeria. A sixty-item questionnaire was drawn to elicit information from the students. The researcher found out that faculties of study by the students do not significantly influence the performance of students in the Use of English course.

Madu (2006) investigated the causes of the differences in the performance of students in their specific courses of study in the various faculties at the university. The investigator used four faculties in the University of Ado-Ekiti. The sample size for the study was eight hundred (800) students. Even though the investigator arrived at possible causes of differences in performance among students, there were no differences found in the performance of students in their specific courses in the different faculties, taking an average from the result of a period of five years. The implication of the above is that if one faculty performs highly this year, it may not be so in the next year. Thus, if the average of a period of time is considered there would be no difference in the performance of students in the various faculties.

Similarly and Yohana (2010) conducted a research to determine whether faculty of study has any influence on performance of students in the Use of English course. The researcher drew a sample of six hundred and fifty (650) second year students from Ahmadu Bello University, Zaira, Nigeria. The faculties of arts and science were sampled with an equal number of students. The finding was that there was no significant difference in performance. This means that faculty does not significantly influence academic achievement in Use of English. Dogoni (2011) researched on the influence of course of study on the academic achievement of students in Use of English. The researcher drew a sample of three hundred students from three departments in the Faculty Arts: English, History, and Islamic Studies. The data used were from a questionnaire and the Use of English course scores. The finding was that there was no significant influence of the course they were offering at the university on their academic achievement in Use of English course.

The study by Isabuome (2009) was on students' academic achievement in Senior School Certificate English Language examination and performance in academics in their faculties of study. With a sample of seven hundred and fifty (750) students in senior secondary schools in Ogun State, Nigeria, the study showed no significant difference in the academic achievement of students in Senior School Certificate English Language examination and in faculty of study. Ikoh (2010), in a study on the effect of course of study on the performance of students in 
the Use of English course at the university, reported no significant influence. The researcher had utilized four hundred (400) undergraduate students in the Departments of Guidance and Counseling, and Physics. This implies that the course of study of a student does not significantly influence performance in the Use of English course.

\section{Method}

The ex-post factor research design was used for the study. The area of study was Cross River University of Technology, Calabar, with other campuses in Obubra, Ogoja and Okuku, all in Nigeria. The study population comprised the final year students of the university. Random sampling technique was adopted to arrive at a sample size of nine hundred and sixty four (964) students from the departments. The instruments for data collection were the scores by each student in the Senior School Certificate English Language examination derived from their grades, scores from the Use of English course at the university, and their cumulative grade point averages in their entire courses of study at the university. The procedure for data collection was that the researchers went personally from one campus of the university to another and from one department to another to collect the data. The data were analysed to reflect the hypotheses using mean, standard deviation and analysis of variance.

\section{Results/Discussion}

Hypothesis 1: Students' faculty, academic achievement in Senior School Certificate English Language examination and Use of English do not significantly contribute to the variance in the academic performance in specific courses of study. Simultaneous multiple regression statistics was used in testing the hypothesis. The results were as shown in Tables 1 and 2.

Table 1. First order inter-correlation of the variables

\begin{tabular}{llllll}
\hline \multicolumn{2}{l}{ Variables } & 1 & 2 & 3 & 4 \\
\hline 1. & Faculty & 1.000 & .033 & .032 & .055 \\
2. & Senior School Certificate examination & & 1.000 & $.066^{*}$. & $109^{*}$ \\
3. & Use of English & & & 1.000 & $.095^{*}$ \\
4. & Performance in courses of study & & & & 1.000 \\
\hline
\end{tabular}

${ }^{*} \mathrm{p}<.05 \quad \mathrm{df}=962 \quad$ Critical $\mathrm{r}=.062$

Table 2. Regression analysis of variance and regression statistics of faculty, academic achievements in Senior School Certificate English Language Examination, Use of English and specific courses of study

\begin{tabular}{|c|c|c|c|c|c|c|c|c|}
\hline $\begin{array}{l}\text { Source of } \\
\text { Variation }\end{array}$ & \multicolumn{2}{|c|}{$\begin{array}{l}\text { Sum of } \\
\text { Squares }\end{array}$} & Df & $\begin{array}{l}\text { Mean } \\
\text { Squares }\end{array}$ & $\mathbf{F}$ & $\begin{array}{l}\text { Sig } \\
\text { Level }\end{array}$ & $\mathbf{R}$ & $\mathbf{R}^{2}$ \\
\hline Regression & \multicolumn{2}{|c|}{1937.394} & 3 & 645.798 & $7.182 *$ & .000 & .148 & .022 \\
\hline Residual & \multicolumn{2}{|c|}{86324.481} & 960 & 89.921 & & & & \\
\hline Total & \multicolumn{2}{|c|}{88261.876} & 963 & & & & & \\
\hline Predictors & \multicolumn{3}{|c|}{$\begin{array}{l}\text { Unstandardized } \\
\text { coefficients }\end{array}$} & $\begin{array}{l}\text { Standardized } \\
\text { coefficients }\end{array}$ & $\mathrm{T}$ & $\begin{array}{l}\text { Sig } \\
\text { level }\end{array}$ & & \\
\hline Variables & \multicolumn{3}{|c|}{ b stdd Error } & $\beta$ & & & & \\
\hline Constant & $\begin{array}{l}58.28 \\
4\end{array}$ & 1.826 & & & 31.914 & .000 & & \\
\hline Faculty & .280 & .183 & & .049 & 1.531 & .126 & & \\
\hline Sen. Sch.Cert & .044 & .014 & & .102 & $3.178^{*}$ & .002 & & \\
\hline Use of Eng. & .074 & .027 & & .086 & $2.701 *$ & .007 & & \\
\hline
\end{tabular}


Table 1 shows the first-order inter-correlation of the variables. From the table, none of the variables correlates significantly with faculty. The rest of the correlations are statistically significant at .05 levels of significance. Table 2 which is the regression statistics proper, shows that the calculated multiple correlation coefficient, R, is .148. This implies that 2.2 percent (i.e., $\mathrm{R}^{2} \times 100 \%$ ) of the variance in students' academic performances in specific courses can be accounted for by their faculty, and academic achievement in Senior School Certificate English Language Examination and Use of English course. The result of the regression analysis of variance shows that the calculated $\mathrm{F}$ value is 7.182 , which is significant at .05 significant level. The significant calculated F value implies that the calculated multiple correlation coefficient, (.148) is also statistically significant and at least one of the variables contributes significantly to the variance in the students' academic performances in specific courses. The calculated $t$ values for Senior School Certificate $(t=3.178)$ and Use of English $(t=2.701)$ are both statistically significant indicating that both of them contribute significantly to the variance in students' academic performance in specific courses. Thus, the null hypothesis is rejected. The regression equation is: Performance in specific courses of study $=58.284+.280$ Faulty +.044 Senior School Certificate +.074 Use of English. The standardized coefficients indicate that Senior School Certificate English Language academic achievements ( $\beta=3.178)$ contribute slightly more than Use of English $(\beta=2.701)$ to the variance in academic performances in specific courses. Therefore, faculty of students does not significantly contribute to the variance in academic performances in specific courses of study.

The finding of this research is in agreement with Hussein (2009) who found out that there is significance among achievement in Senior School Certificate English Language, performance of students in Use of English course, and in their specific courses of study. Suffice it to say that there are overwhelming evidences from literature, that there is correlation between students' achievement in Senior School Certificate English Language and Use of English course in the university. This is deduced from the fact that knowledge develops and good performance is usually applauded. Thus, while low achievers will strive to improve, the high achievers will want to surpass the present achievement or, at best, sustain it. Lawani's (2011) finding is also supported by the finding of this study.

Hypothesis 2: There is no significance difference in the academic achievement of students in various faculties in Senior School Certificate English Language examination. Students from seven faculties in the sampled University were used for study. Therefore, one-way analysis of variance was used in testing the hypothesis. The results of the data analysis were as shown in Table 3.

Table 3. Mean, standard deviation and one-way analysis of variance of the performance of students in various faculties in Senior School Certificate English Language examination

\begin{tabular}{|c|c|c|c|c|c|}
\hline Faculty & $\mathbf{N}$ & $\mathbf{X}$ & & SD & \\
\hline Agriculture & 14 & 66.286 & & 11.090 & \\
\hline Education & 367 & 67.087 & & 10.204 & \\
\hline Engineering & 170 & 66.171 & & 9.973 & \\
\hline Environmental Science & 110 & 67.818 & & 11.651 & \\
\hline Management. Science & 142 & 67.366 & & 9.786 & \\
\hline Science & 96 & 72.698 & & 63.261 & \\
\hline Communication Tech. & 65 & 65.492 & & 10.204 & \\
\hline Source of & Sum of & Df & Mean & $\mathrm{F}$ & Sig. level \\
\hline Variation & Squares & & Squares & & \\
\hline Between groups & 3252.969 & 6 & 542.162 & 1.100 & .360 \\
\hline Within groups & 471657.900 & 957 & 492.850 & & \\
\hline Total & 474910.869 & 963 & & & \\
\hline
\end{tabular}

${ }^{*} \mathrm{p}<.05 \quad \mathrm{df}=(6,957) \quad$ Critical $\mathrm{F}=2.10$

The result in Table 3 indicates that students in Faculty of Science have the highest mean $(x=72.698, \mathrm{~S}=63.26)$ followed by those in Faculty of Environmental Science $(\mathrm{x}=67.818, \mathrm{~S}=11.651)$, Management science ( $\mathrm{x}$ $=67.366, \mathrm{~S}=9.786)$, Education $(\mathrm{x}=67.087, \mathrm{~S}=10.204)$, Agriculture $(\mathrm{x}=66.286, \mathrm{~S}=11.090)$, Engineering $(\mathrm{x}=$ 
$66.171, \mathrm{~S}=9.973)$ and lastly Communication Technology $(\mathrm{x}=65.492, \mathrm{~S}=1 \mathrm{O} .204)$. The result of the one-way analysis of variance indicates that the calculated $\mathrm{F}$ value is 1.100 . Since this is less than the critical $\mathrm{F}$ value of 2.10 at $(6,957)$ degrees of freedom and .05 level of significance, it means that the calculated $F$ value is not statistically significant. This implies that there is no significant difference in the academic achievement in the various faculties in Senior School Certificate English Language examination. Therefore, the null hypothesis is upheld.

This finding supports the finding by Aneke (2009). The researcher sought to establish the correlation between students' performance in the Senior School Certificate English Language examination and their performances in faculties of study. The finding showed negative relationship. The finding of the investigation by Madu (2006) is supported by the finding of this study. Madu (2006) investigated the causes of differences in performance of students in various faculties in the University. The investigator found no differences that were significant. However, it must be emphasized that if any difference is found, it will relate to a particular year. But if a longitudinal survey of performance of students in the faculty is taken for a period, significant difference may not be found. In the same vein, the report of this study agrees with that of Isabuome (2009) who reported no difference in the academic achievement of students in Senior School Certificate English Language examination and in faculty of study.

Hypothesis 3: There is no significant influence of faculty on students' academic achievement in the Use of English course. The hypothesis was tested using one-way analysis of variance since there are more than two faculties. The results were as presented in Table 4.

Table 4. Mean, standard deviation and one-way analysis of variance of students' academic achievement in the Use of English course according to faculty

\begin{tabular}{|c|c|c|c|c|c|}
\hline Faculty & $\mathbf{N}$ & $\mathbf{X}$ & & SD & \\
\hline Agriculture & 14 & 52.714 & & 13.425 & \\
\hline Education & 367 & 54.311 & & 10.018 & \\
\hline Engineering & 170 & 53.500 & & 11.176 & \\
\hline Environmental Science & 110 & 54.473 & & 11.599 & \\
\hline Management Science & 142 & 54.972 & & 11.642 & \\
\hline Science & 96 & 55.573 & & 10.082 & \\
\hline Communication Tech. & 65 & 54.292 & & 11.561 & \\
\hline $\begin{array}{l}\text { Source of } \\
\text { Variation }\end{array}$ & $\begin{array}{l}\text { Sum of } \\
\text { Squares }\end{array}$ & $\mathrm{Df}$ & $\begin{array}{l}\text { Mean } \\
\text { Squares }\end{array}$ & $\mathrm{F}$ & Sig. level \\
\hline Between & 60.032 & 6 & 60.005 & $.479^{*}$ & .824 \\
\hline \multicolumn{6}{|l|}{ Groups } \\
\hline Within groups & 119868.200 & 957 & 125.254 & & \\
\hline Total & 120228.232 & 963 & & & \\
\hline
\end{tabular}

${ }^{*} \mathrm{p}<.05 \quad \mathrm{df}=(6,957) \quad$ Critical $\mathrm{F}=2.10$

As shown in Table 4, students in Faculty of Science have the highest mean academic achievement in the Use of English course $(x=55.573, \mathrm{~S}=10.082)$. They are followed in decreasing order of magnitude, by students in the Faculty of Management Science $(x=54.972, S=11.642)$, Environmental Science $(x=54.473, \mathrm{~S}=11.599)$, Education $(\mathrm{x}=54.311, \mathrm{~S}=11.018)$, Communication Technology $(\mathrm{x}=54.292, \mathrm{~S}=11.561)$, Engineering $(\mathrm{x}=53.500$, $\mathrm{S}=11.174$ ) and then Agriculture (x 52.714, $\mathrm{S}=13.425$ ). Generally, the mean academic achievements of the students in the course are just within average for all the faculties.

The result of the analysis of variance shows that the calculated $\mathrm{F}$ value is .479 , which is less than the critical $\mathrm{F}$ value of 2.10 at .05 significance level and 6,957 degrees of freedom. This means that the calculated $\mathrm{F}$ value is not statistically significant, implying that there is no significant influence of faculty on students' academic achievement in the Use of English course. Therefore, the hypothesis is retained. 
The finding is in consonance with the finding of Fagbemi (2008) who reported that the faculty students are admitted into does not influence significantly the performance of the students in academics since all have opportunities of advancing on the academic ladder, in the various courses of study. This implies that students aim at performing highly no matter the faculty of admission since good performance in any faculty is a source of pride, not only to the performer, but also to the larger society.

The result of this study supports that of Toffai (2007) whose study was on performance of students in the Use of English and the effect on achievement in academics. The finding was that faculties do not significantly influence the performance of students in the Use of English. In like manner, the finding of this work agrees with that of Yohana (2010). The researcher sought to determine whether faculty of study has any influence on students' performance in Use of English course. The researcher found out that there was no significant influence of the faculty of study of the students on academic achievement in the Use of English course. This means that performance in Use of English is a function of studying hard, not because of the faculty of admission.

The result of this study also agrees with that of Dogoni (2011) who researched on the influence of course of study on the academic achievements of students in Use of English. The finding of the research revealed that the course of study of a student at the University does not significantly influence academic achievement in the Use of English. The implication of this is that once a student is studious in the chosen course of study, it will have relative positive effect on performance in the course offered. The finding of this study is in agreement with that of Ikoh (2010) who had found no significant influence of course of study of students on their performances in Use of English course.

Hypothesis 4: There is no significant influence of faculty on students' performance in specific courses of study. The hypothesis was also tested with one-way analysis of variance. The results of the data analyses were as shown in Table 5.

Table 5. Mean, standard deviation and one-way analysis of variance of students' performances in specific courses of study according to faculty

\begin{tabular}{|c|c|c|c|c|c|}
\hline Faculty & $\mathbf{N}$ & $\mathbf{X}$ & & SD & \\
\hline Agriculture & 14 & 65.571 & & 7.910 & \\
\hline Education & 367 & 65.875 & & 9.743 & \\
\hline Engineering & 170 & 65.488 & & 9.866 & \\
\hline Environmental Science & 110 & 66.600 & & 9.737 & \\
\hline Management Science & 142 & 67.232 & & 9.160 & \\
\hline Science & 96 & 67.156 & & 9.098 & \\
\hline Communication Tech. & 65 & 66.723 & & 9.540 & \\
\hline $\begin{array}{l}\text { Source of } \\
\text { Variation }\end{array}$ & $\begin{array}{l}\text { Sum of } \\
\text { Squares }\end{array}$ & Df & $\begin{array}{l}\text { Mean } \\
\text { Squares }\end{array}$ & $\mathrm{F}$ & Sig. level \\
\hline Between & 400.334 & 6 & 66.722 & $.727^{*}$ & .628 \\
\hline \multicolumn{6}{|l|}{ Groups } \\
\hline Within groups & 87861.542 & 957 & 91.809 & & \\
\hline Total & 88261.876 & 963 & & & \\
\hline
\end{tabular}

$* \mathrm{p}<.05 \quad \mathrm{df}=(6,957) \quad$ Critical $\mathrm{F}=2.10$

As shown in Table 5, students in Management Science had the highest mean academic performance in course of study $(x=67.232, S=9.160)$. They were followed in decreasing order of magnitude by students in Faculty of Science $(\mathrm{x}=67.156, \mathrm{~S}=9.098)$, Communication Technology $(\mathrm{x}=66.723, \mathrm{~S} 9.540)$, Environmental Science ( $\mathrm{x}$ $=66.600, \mathrm{~S}=9.737)$, Education $(\mathrm{x}=65.875, \mathrm{~S}=9.743)$, Agriculture $(\mathrm{x}=65.571, \mathrm{~S}=7.910)$ and Engineering $(\mathrm{x}$ $=65.488, \mathrm{~S}=9.866$ ). The result of the analysis of variance indicates that the calculated $\mathrm{F}$ value is .729 which is far less than the critical $\mathrm{F}$ value of 2.10 at .05 significance level and 6,957 degrees of freedom. This implies that the calculated F is not statistically significant. In other words, there is no significant influence of faculty on students' academic performance in specific courses of study. Thus, the null hypothesis is retained. 
The finding of this study agrees with that of Muktar (2000) who studied the influence of faculty on the academic achievement of students in programmes of study. The researcher found no influence of faculty on the academic achievement of students in their programmes of study. This means that the high or low academic achievements of students are not influenced by the faculty they belong to but by their individual attitudes towards studies. The finding of this study is buttresses that by Nnolim (2004) who had studied students' performances in Senior School Certificate English Language examination vis-a- vis their level of maturation. The researcher found out that just the name of the faculty of study does not significantly influence students' achievement in academics. Nnolim (2004) reported that the level of academic achievement of students in Senior School Certificate English Language examination was not influenced by whether they were arts, science or technical students. What influences performance is the level of preparation for the examination. The finding by Ominagwu (2006) is supported by the finding of this research. The researcher reported no significant influence on the academic performance of students on the basis of course of study.

\section{Conclusion}

It is emphasized here that the level of academic achievement by students depends largely on the preparedness of the students to be committed to or engaged in worthwhile studies in their chosen courses of study. The faculty of study merely provides an enabling academic environment for the learners. This has been confirmed by this study, and others. Thus, the Senior School Certificate English Language and Use of English significantly contribute to the variance in students' academic performance in specific courses of study. The non-existence of significant difference between the academic achievements of students in various faculties in Senior School Certificate English Language examination indicates that admission of students into any faculty cannot be premised on achievement in Senior School Certificate English Language performance. Again, since faculty does not significantly influence students' academic achievement in the Use of English course, it is hereby concluded that performance in Use of English course in the university cannot be determined by students' faculty of study. Finally, performance of students in their specific courses of study is consequent upon their disposition to study hard, not because of the faculty they are admitted in to study.

\section{References}

Aneke, C. U. (2009). Correlates between students' achievement in Senior School Certificate English Language examination and faculties of study (Unpublished master's thesis, University of Ife, Ile-Ife, Nigeria).

Baugh, A. C. (1982). History of English Language. New York: Double Publishers.

Dagila, M. D. (2010). Students' academic performance in Senior School Certificate English Language examination as a predictor of performance in use of English course. (Unpublished doctoral dissertation). Ahmadu Bello University, Zaria, Nigeria.

Dogoni, D. A. (2011). Influence of course of study on the academic achievement of students in use of English. (Unpublished master's thesis). Bayero University, Kano, Nigeria.

Ezema, P. A. (2000). Towards enhancing students' awareness of the utilitarian value of the English Language. Teacher Education, 2(1), 93-96.

Fagbemi, D. O. (2008). Influence of faculty of study on the self-esteem of students and performance in course of study (Unpublished doctoral dissertation, University Ibadan, Nigeria).

Geishina, M. A. (2008). Correlates between students' achievement in Senior School Certificate English Language examination and performance in Use of English and communication skills course (Unpublished master's thesis, University of Ilorin, Nigeria).

Hussein, A. B. (2009). Relationship among achievement in Senior School Certificate English Language examination, level of performance in Use of English course and in courses of study. Journal of Studies in Education, 3(1), 19-22.

Isabuome, N. D. (2009). Students' academic achievement in Senior School Certificate English Language examination and performance in faculty of study. Journal of Multi-disciplinary Studies, 3(1), 38-42.

Lawani, S. D. (2011). Correlation between achievement of undergraduate students in Senior School Certificate English examination and in Use of English. Journal of Studies in Education, 4(1), 22-25.

Madu, B. C. (2006). Investigation into the causes of differences in performance of students in various faculties. Journal of Studies in Education, 2(1), 66-73.

Muktar, S. M. (2000). Influence of faculty on the academic achievement of students in programmes of study. 
Journal of the Nigerian Society for Educational Psychologists, 1(1), 80-86.

Nimyel, D. A. (2010). Poor performance in West African Examination Council examinations. Retrieved from http://compassnewspaper.com

Nnolim, B. U. (2004). Maturational level, course of study and students' performance in Senior School Certificate English Language examination. Journal of General Studies, 2(1), 36-43.

Ominagwu, E. D. (2006). Course of study and its influence on the academic performance of Masters' degree students. Journal of Multi-disciplinary Studies, 3(1), 56-61.

Toffai, D. G. (2007). Students' performances in the Use of English and the effect on achievement in programmes of study. Journal of Empirical Studies, 2(1), 101-106.

Yohana, S. M. (2010). Effect of faculty of study on students' performance in the use of English and communication skills. Journal of Research in Advanced Studies, 2(1), 43-50.

Yusuf, O. M. (2000). English Language as a vehicle for the enhancement of teacher education in Nigeria in the $21^{\text {st }}$ century. Teacher Education: A Journal of the Association of Teacher Educators in Nigeria, 2(1), 154-157.

\section{Copyrights}

Copyright for this article is retained by the author(s), with first publication rights granted to the journal.

This is an open-access article distributed under the terms and conditions of the Creative Commons Attribution license (http://creativecommons.org/licenses/by/3.0/). 